\title{
INVOLVEMENT OF EMPLOYEES IN OPERATIONAL PLANNING OF MANUFACTURING ENTERPRISES: LATVIA EXPERIENCE
}

\author{
Diāna Līduma, Inese Lūsēna-Ezera \\ Liepaja University, Latvia \\ E-mail: diana_liduma@inbox.Iv, inese.lusena-ezera@liepu.Iv
}

\begin{abstract}
The main feature of teamwork is a common goal, and the involvement of employees is essential to its achievement. In a wider scope, it is understood not only by the involvement of employees in decisionmaking but also as the involvement of employees in operational planning and strategic issues. Research aim is to find out whether the involvement of employees in decision-making, goal setting and planning is inherent in manufacturing enterprises. According to a survey of 268 different level employees of 25 manufacturing enterprises in Latvia, it was found out that involvement of all employees in the decisionmaking process is not perceived by the enterprises 'performance and strategic planning, and the involvement of employees in decision-making and goal setting can only be seen within the department.

Keywords: decision-making, employee involvement, goal setting, operational planning, manufacturing enterprise, teamwork
\end{abstract}

\section{Introduction}

A correctly chosen strategy in an enterprise promotes its long-term competitiveness and operational development in the market. A proper strategic planning can also have a huge impact on the enterprise's operations and long-term value (Hofs \& Alsina, 2019; Mankins \& Steel, 2009). It requires such decision-making as the choice of technology, allocation of resources, development of the necessary skills, etc. It is the way the decisions are made throughout the organization that has a very serious impact on the strategy, as the strategy will only be understood and implemented if it receives support in decisions for resource allocation made at all levels of the enterprise (Bower \& Gilbert, 2009). "With the help of strategic, tactical and operational plans, the enterprise's management and employees plan the use of the enterprise's resources in compliance with the set goals" (Hofs \& Alsina, 2019, p.504). Due to limited resources also in the enterprises' daily life, managers will have to take into account decisions refusing from the implementation of one activity and reallocating the organization's resources to other activities (Caune \& Dzedons, 2009), which are hard to be implemented without the support of employees of different levels. According to a number of researchers, the enterprise's strategy development requires employees' participation, as does day-to-day planning and decision-making (Bower \& Gilbert, 2009; Blanchard \& Johnson, 2008; Caune \& Dzedons, 2009; Hofs \& Alsina, 2019). This is justified both by the above mentioned and the fact that responsibilities in enterprises are divided between different individuals and entities, which means that not only power but also knowledge in enterprises is scattered and located in unexpected enterprise's structural units, influencing how the strategy unfolds (Bower \& Gilbert, 2009). "Nowadays important decisions in an organization are hardly ever made by one person" (Praude, 2012, p.351). Involvement of 
Diāna LİDUMA, Inese LŪSĒNA-EZERA. Involvement of employees in operational planning of manufacturing enterprises: Latvia experience

PROBLEMS

OF MANAGEMENT IN THE $21^{\text {st }}$ CENTURY Vol. 16, No. 2, 2021

88

employees in decision-making gives the opportunity to receive more information and knowledge, to combine different experience and professionalism, to obtain multiple original ideas and alternatives, different views on the same problem (Praude, 2012; Ruperte, 2010). Despite the fact that group decision-making is a relatively long and labour-intensive process, which has to be organized correctly, in the case of an effective decision, the costs will be justified, since it is possible to choose the best of the various alternatives, a much more precise decision has been made and the final decision has many supporters (Praude, 2012). It is the planning process that unites the enterprise's employees to achieve common goals (Hofs \& Alsina, 2019). Similarly, to common decisions, a common view of the goal in the enterprise also serves as: a source of inspiration - an incentive to achieve it by developing the necessary resources and capabilities; basis for better quality decisions; promotes creative and innovative action; maintains enthusiasm (Bower \& Gilbert, 2009; Caune \& Dzedons, 2009; Hofs \& Alsina, 2019). "Operations managers can refocus and improve strategy in particularly innovative ways" (Bower \& Gilbert, 2009, p.133). As researchers have mentioned, managers and employees become surprisingly creative and innovative if they understand and support the enterprise's mission, goals and strategy (Caune \& Dzedons, 2009). And it is the ability to see the vision that is also part of the employees' broader capacity to develop understanding of what the organization might look like in the future (Gratone, 2004). The goal in the strategic planning process is to prepare and unite the enterprise's employees in order to meet the strategic goals (Hofs \& Alsina, 2019), therefore, gaining the understanding and participation of all managers and employees in the strategic management process should be set as the most important goal (Caune \& Dzedons, 2009). The efficiency of the decision-making process itself is also determined by how the manager has managed to involve other employees into this process (Praude, 2012). The development of a strategy is a process in which the involvement of employees means that they begin to feel part of the company, they want to support it and are aware of the link between their own contribution and the enterprise's performance, participation ensures the interest in making the necessary changes, increases the organization's ability to eliminate problems and helps to improve products by creating a team that works with motivation and is able to change flexibly (Caune \& Dzedons, 2009; Hill et al., 2014; Hofs \& Alsina, 2019). This mentioned performance is ensured by the teamwork approach in enterprises, taking into account that the most characteristic features of teamwork are: ability to work in a coordinated way to achieve common results, positive thinking, flexible and variable division of functions between employees, professionalism and mutual cooperation in the duties performance (Zinkevich-Evstigneeva, 2004). As pointed out by Forands (2003), the team is inherent in common understanding of values, internal interconnectedness, expression of feelings, trust, interpersonal communication skills, coherence, listening, conflict resolution, consensus and cooperation (Forands, 2003). It is topical for teams to have a common external goal, mutual division of roles and tasks, responsibility for the result and jointly made decision (Ruperte, 2010). Workforce involvement and teamwork to address strategic issues in enterprises, collective decision-making, involving employees in discovering and solving company problems, creating conditions for the use of each employee's abilities and initiative, and providing support for team leaders' activities strategic vision, are considered to be the hallmarks of a highly efficient organization (ZinkevichEvstigneeva, 2004). Complementing this with an understanding of a common goal and expected outcome, a common view of the approach chosen to solve the tasks, increase of responsibility for individual performance, cooperation and mutual support in the performance of direct responsibilities, immediate and constructive conflict resolution, a friendly and supportive atmosphere, and team spirit in general, must also ensure the functioning of a healthy company (Sartan, 2005). Thomas Bothe (2017), a strategy and leadership coach practicing in Europe, believes that team members have personally identified with belonging to a team in order to achieve a common goal (Bothe, 2017). In this way, an effective implementation of change 
(Adizes, 2018; Caune \& Dzedons, 2009), launch of new products and development of existing ones, creative and innovative approach to tasks (Hill et al., 2014; Vīksna, 2009) can be achieved. According to Linda A. Hill et al. (2014): "The ultimate innovation will almost always be the collective result which has been achieved due to the group's interactions" (Hill et al., 2014, p. 41). The compliance of employees' behaviour with the business objectives also has an impact on the enterprise's performance and specific financial results (Gratone, 2004), the same way as productivity, both qualitatively and quantitatively, is best achieved with the help of people (Blanchard \& Johnson, 2008; Ozolina-Ozola, 2009). A value-oriented organization also requires a unified employees' view (Barret, 2008). "The deep consensus on priorities and the set of actions that will enable an enterprise to achieve them lies in the essence of a strong culture" (Kristensen et al., 2009, p.164), just as teambuilding itself is based on a corporate culture that has certain values and norms (Forands, 2003). According to the management specialist I. Ruperte (2010), "The team determines the efficiency of the organization and the readiness for change and, most often, the viability of the organization" (Ruperte, 2010, p. 154). It should be remembered that the main role of the staff in the organization is related to the choice of the type of their activity organization and it is the staff that makes the technology, through its skilful application, become the creator of added value in the company (Freemantle, 2006; Praude, 2012; Sinicins, 2009; Svikis, 2018). People of an organization, as the most valuable part of resources, are the ones who provide the main advantages of competitiveness, because the development and implementation of new quality ideas depends on them (Praude, 2012). As new knowledge enters production and technology changes, it is the competencies of those who work that can take advantage of technology (Sinicins, 2009; Svikis, 2018). "There is a significant difference between people as a value and traditional and technological values or means, understanding the difference mentioned above, the way of thinking and operating style changes in the organization" (Gratone, 2004, p. 3-4). "A business-level strategy can only be implemented with the participation of people (Gratone, 2004, p. 4), since the key to success in every enterprise is the employees' ability to react quickly and understand changes in the surrounding environment, as well as to take into account the current circumstances when planning further activities" (Hofs \& Alsinga, 2019, p.509). According to Ichak Kalderon Adizes (2018), one of the world's leading management experts: "A complementary team is needed to make effective decisions" (Adizes, 2018, p. 324).

\section{Research Problem}

As business management approaches change, the pursuit of high performance by manufacturing enterprises remains unchanged. Business leaders are constantly looking for and implementing new approaches and tools in the management of manufacturing enterprises, in enhancement of their enterprise's operational outcomes and increasingly appreciating the importance of the human factor in their companies. One of the potentially applicable tools is teamwork in manufacturing enterprises in order to achieve the specified work results. In the absence of a team approach in business planning, goal setting and decision-making processes, the manufacturing enterprise's management risks low competitiveness, quality problems, unfulfilled orders in time, performance of incomprehensible tasks on daily basis, lack of creativity among employees, low job satisfaction and loyalty in general (Bikfalvi, 2011; FloresFillol et al., 2017; Grant \& Hallam, 2016; Maginn, 1994; West, 2004; etc.). Lack of cooperation at the functional level hinders problem-solving in the enterprise (Caune \& Dzedons, 2009), and strategic planning fails if it focuses on individual business units (Mankins \& Steel, 2009). The research aim was to find out whether the involvement of employees in decision-making, goal setting and planning is inherent in manufacturing enterprises. 
Diāna LĪDUMA, Inese LŪSĒNA-EZERA. Involvement of employees in operational planning of manufacturing enterprises: Latvia experience

$\begin{array}{r}\text { PROBLEMS } \\ \text { OF MANAGEMENT } \\ \text { IN THE 21 } 1^{\text {st }} \text { CENTURY } \\ \text { Vol. 16, No. 2, } 2021 \\ \hline 90\end{array}$

\section{Research Focus}

In manufacturing companies, it is especially important for employees to know on a daily basis what the indicators of each production department are in relation to what has been planned, because operative information about the results can be very motivating to work as efficiently as possible (Hofs \& Alsina, 2019). "An ongoing planning process involving the entire organization is an important prerequisite for achieving the enterprise's long-term economic goals" (Hofs \& Alsina, 2019, p. 504). Therefore, the question is topical whether and to what extent the workforce participation and problem-solving in a team are inherent in manufacturing enterprises. A serious mistake is the belief that strategic planning is exclusively a function of top-level management - it leads to unrealizable strategies, strategies that do not work and tense mutual relationships (Caune \& Dzedons, 2009). "Most strategy analysts ignore the role of work managers in strategy results achievement, assuming that these managers are too tied to the requirements of operations to think strategically" (Bower \& Gilbert, 2009, p. 133), forgetting that hierarchy can hinder the free flow of information and the emergence of diverse ideas (Hill et al., 2014), or the fact that it is in times of crisis that common ground and concerted action are essential (Caune \& Dzedons, 2009), where it is the operational leaders who have a very real impact (Bower \& Gilbert, 2009). Taking into account the series of daily unforeseen events, decisions must be made immediately, so the awareness of the enterprise's goals and objectives, as well as the planning of resources in which employees have participated, is important for making quality and correct daily decisions (Hofs \& Alsina, 2019). It is important to understand that much of the planning can and should be done by the lowest level executives who are the closest to the facts and purchasers. Therefore, corporate level planners have a responsibility to facilitate decision making for lower-level managers (Caune \& Dzedons, 2009). However, the 'thinking with the herd' inherent in group decisions should also be largely avoided, but it should be borne in mind that strategic planning is only successful if strategic decision-makers make full use of all the information available to them. This means that it will only be successful if leaders at all levels are involved (Caune \& Dzedons, 2009; Owen, 2017). "The primary task of management is to get people to work together systematically" (Kristensen et al., 2009, p. 164), but in order to develop a strategic approach to people, a strong dialogue must be ensured throughout the organization (Gratone, 2004). It is also important to ensure that employees receive feedback on the development of the company in the area in which the employee has been involved (Hofs \& Alsinga, 2019). According to the researcher Gratone (2004), this requires both a new kind of mindset and a new kind of activity in the enterprise - a kind of thinking that puts the search for purpose at the centre and an activity that creates a common vision, full awareness of the situation and a wide range of multifunctional work group involvement based on human resources strategy (Gratone, 2004). "The art of management is about making things happen through people you do not control" (Owen, 2017, p. 208). In addition, making effective decisions requires finding long-term common interests for the people who are needed to implement the decisions made (Adizes, 2018). When focusing on relationships with employees, an enterprise should be established where the set of core values is understood and demonstrated through the organization (Wellington, 2017). Observing that the enterprise must be designed to be able to move towards strategic goals, employees need to understand what they are and how each decision made contributes to their achievement (Hofs \& Alsina, 2019). The lack of goals and objectives, both for the owner and for employees, is often a cause for concern, as a result of which resources are misused and fail to achieve the anticipated (Hofs \& Alsina, 2019). It also reveals the main reason for the need to involve employees in operational planning processes, their own goal determination and the corresponding decision making towards them. 
Diāna LİDUMA, Inese LŪSĒNA-EZERA. Involvement of employees in operational planning of manufacturing enterprises: Latvia experience

\section{Research Methodology}

\section{General Background}

The main attention in the research has been paid to the potential of teamwork application in manufacturing enterprises in Latvia - business planning, decision-making and common goal determination. In order to find out whether the operation of manufacturing enterprises is inherent in the employees' involvement in decision-making, goal setting and operational planning, 268 managers and employees of various levels (both manufacturing and administrative function performers) in 25 manufacturing enterprises in Latvia were interviewed that are economically active and operate in one of the subbranches of the NACE Revision 2 Group C "Manufacturing Industry" within the year 2019/2020.

\section{Sample}

The breakdown of enterprises by subgroup section shows that in terms of share the most surveyed subgroups C10 - Manufacture of Food Products - enterprises (24\%; 6) and subgroups C25 - Manufacture of Prefabricated Metal Products, except for machinery and equipment - enterprises $(12 \%$; 3$)$, with a similar distribution for the number of enterprises surveyed in industry subgroups C14 (Manufacture of Wearing Apparel), C16 (Manufacture of Wood and Wooden and Cork Products, except for furniture; Manufacture of Straw Articles and Plaiting Materials), C28 (Manufacture of Equipment, Mechanisms and Machines N.E.C.) and C29 (Manufacture of Motor Vehicles) - respectively 8\% (2) enterprises in each and 4\% (1) enterprises in the other industry subgroups.

Based on the size of the company in terms of the number of employees, $12 \%$ (3) of the 25 enterprises involved in the study correspond to a large company ( 250 and more employees), $32 \%$ (8) to a small company (up to 49 employees) and 56\% (14) to a medium-sized company (50 to 249 employees) group.

Looking at the enterprise's operating duration, $32 \%$ (8) of the enterprises with a duration of up to 10 years, $36 \%$ (9) with a duration of $11-20$ years and $32 \%$ (8) with a duration of 21 years or more have participated in the survey.

$15 \%$ (39) of all enterprises surveyed sell their products in the domestic market, $52 \%$ (140) in the international market, and the rest 33\% (89) sell their products in both the domestic and international markets. $21 \%$ (57) of companies start their production before having received an order and $79 \%$ (211) produce after having received an order.

In $28 \%$ (74) cases of the production process, most of the work is done by employees and the equipment is used only as an aid, in $12 \%$ (33) of the production process most of the work is done by special equipment, but workforce is used to monitor the process, whereas $60 \%$ (161) of the respondents note that in the production process the enterprise uses special equipment and employees' skills to work with them equally.

Among the 268 employees of different levels involved in the study, 32\% (85) of the respondents' position determines they have other staff under their authority, but $68 \%$ (183) have no other staff under their authority - 3\% (7) manage the company, 20\% (53) manage a department and $78 \%$ (208) are other employees of the company. The average length of the respondents' service in the company is 4.7 years (maximum length of service: 37 years; minimum length of service: 0.5 years). 
Diāna LİDUMA, Inese LŪSĒNA-EZERA. Involvement of employees in operational planning of manufacturing enterprises: Latvia experience

OF MANAGEMENT

IN THE $21^{\text {st }}$ CENTURY Vol. 16, No. 2, 2021

\section{Instrument and Procedures}

To achieve the aim of this study, an online questionnaire was worked out to clarify:

- What problem-solving issues are the enterprise's employees in the manufacturing companies involved in?

- Are employees involved in the decision-making, elaboration of the enterprise's development goals and plans?

- In what problem-solving issues would the employees' participation be the most relevant in the manufacturing enterprise?

The survey was conducted on the Internet by filling out a specially designed online questionnaire at docs.google.com/forms. The questionnaire consisted of 9 questions. The structure of the questionnaire comprised closed questions:

- 3 questions were formed in the interval scale, allowing the respondents to provide their answers to several statements from 1 (not at all typical) - 5 (very typical) to evaluate the highly effective organizational features in manufacturing enterprises $(9$ statements) and employees' involvement in decision making ( 8 statements), and to provide respondents` answers to 8 statements from 1 (very poor) - 5 (very good) to evaluate a cooperation in manufacturing enterprises;

- 2 questions were formed in ordinal scale, allowing the respondents to provide their answers to 5 statements to evaluate cooperation for the day-to-day performance of employees' duties (scale: not related at all, more unrelated than related, more related than not related, largely related) and to find out the necessity for employees' participation in the management issues of the manufacturing enterprise (scale: employees' participation is necessary, employees 'participation is rather necessary, employees 'participation is rather not necessary, employees `participation is not necessary);

- 4 questions were in nominal scale. To find out, whether the groups of employees independent from the manager are being formed in the manufacturing companies, 1 question with 9 statements were formed in dichotomous scale (answers "yes" and "no"). 1 questions were formed to identify employee involvement in the development of the enterprise's development goals and plans, and respondents had to mark one appropriate answer from the list of the 4 values. 2 questions were formed as multiple response questions: 1) to find out at which of the operational stages in the manufacturing enterprise is the greatest need for the employees' mutual cooperation, respondents were provided to mark the appropriate answer or answers from the list of 14 operational stages and 2) to find out in which of the problemsolving issues relevant to the enterprise employees have been involved during the last year, respondents were provided to mark the appropriate answer or answers from the list of 10 problem-solving issues.

\section{Data Analysis}

The survey results were analysed and the data processed by the authors of the paper within the present study by applying methods of descriptive statistics (frequencies and central tendency), data visualization method, and data reduction. Data reducing were applied with the aim to reflect an ordinal variable "the necessity for employees' participation in the management issues of the manufacturing enterprise" with 4 values (1) employees "participation is necessary, 2) employees ' participation is rather necessary, 3) employees 'participation is rather not necessary, 4) employees 'participation is not necessary) as variable with 2 values - 1) employees ' participation is necessary and 2) employees 'participation is not necessary), 
Diāna LİDUMA, Inese LŪSĒNA-EZERA. Involvement of employees in operational planning of manufacturing enterprises: Latvia experience

thus, only positive and negative responses are used in the analysis of the results. Reducing of

values were applied

- by combining Employees 'participation is necessary and Employees 'participation is rather necessary into one category "Employees 'participation is necessary" and

- by combing Employees 'participation is rather not necessary and Employees` participation is not necessary into one category "Employees' participation is not necessary"

SPSS software (26 version) and MS Excel 2016 were used to analyze the statistical data.

\section{Research Results}

Assessing the researched manufacturing enterprises according to the features of a highly efficient organization, which envisages employees' involvement and joint cooperation in solving issues relevant to the enterprise, the results show that on a scale of 1 (not at all typical) - 5 (very typical), respondents evaluated the given features as partially inherent in their enterprises (the mean rating ranging from 3.09 to 3.88 ).

The respondents indicated their enterprise's efforts to find out and meet customer needs efficiently as the most typical (Mean rating $3.88(S D=1.035)$ ) (Table 1), which in a market economy is reasonable and relevant for every enterprise, hoping for profit as a result of operations.

\section{Table 1}

Evaluation of Highly Effective Organizational Features in Manufacturing Enterprises in Latvia, Average Rating $(n=268)$

\begin{tabular}{lcccc}
\hline Features of a highly efficient organization & Min & Max & $M$ & SD \\
\hline Find out and satisfy customer needs efficiently & 1 & 5 & 3.88 & 1.035 \\
\hline Introduce innovations and evolve & 1 & 5 & 3.69 & 1.107 \\
\hline Allocate existing resources efficiently and wisely & 1 & 5 & 3.53 & 1.061 \\
\hline Continuous learning & 1 & 5 & 3.46 & 1.240 \\
\hline Implement reasonable changes & 1 & 5 & 3.40 & 1.035 \\
\hline Support the team leaders' activity and strategic vision & 1 & 5 & 3.24 & 1.008 \\
\hline $\begin{array}{l}\text { Work together as a whole } \\
\text { Create conditions for the use of each employee's abilities and }\end{array}$ & 1 & 5 & 3.24 & 1.125 \\
\hline $\begin{array}{l}\text { initiative } \\
\text { Involve employees in the enterprise's problem identification and }\end{array}$ & 1 & 5 & 3.18 & 1.051 \\
solving & & 5.09 & 1.088 \\
\hline
\end{tabular}

At the same time, the features of effective organization that are directly related to teamwork are less characteristic of the researched manufacturing enterprises - to involve employees in the enterprise's problem identification and solving (Mean rating $3.09(S D=1.088)$ ), to create conditions for each employee to use their abilities and initiative (Mean rating 3.18 ( $\mathrm{SD}=1.051)$ ), as well as for the company to operate as a whole (Mean rating $3.24(S D=1.125))$. (Table 1)

Noting to what extent the performance of employees' duties in manufacturing enterprises on a daily basis is related to the "involvement and cooperation of other employees" - 51.9\% of respondents indicate that "to a large extent" and another $51.5 \%$ of respondents also "to a large extent" indicate their daily duties "ability to work in concert to achieve a common result" (Table 2). 
Diāna LĪDUMA, Inese LŪSĒNA-EZERA. Involvement of employees in operational planning of manufacturing enterprises: Latvia experience

OF MANAGEMEI IN THE $21^{\text {st }}$ CENTURY Vol. 16, No. 2, 2021

Table 2

Cooperation for the Day-to-day Performance of Employees' Duties, \% ( $n=268)$

\begin{tabular}{|c|c|c|c|c|}
\hline $\begin{array}{l}\text { To what extent is the performance of your daily } \\
\text { duties related to: }\end{array}$ & $\begin{array}{l}\text { Largely } \\
\text { related }\end{array}$ & $\begin{array}{c}\text { More related } \\
\text { than not re- } \\
\text { lated }\end{array}$ & $\begin{array}{l}\text { More unre- } \\
\text { lated than } \\
\text { related }\end{array}$ & $\begin{array}{l}\text { Not related } \\
\text { at all }\end{array}$ \\
\hline Involvement and cooperation of other employees & 51.9 & 29.5 & 16.0 & 2.6 \\
\hline $\begin{array}{l}\text { Ability to work in concert to achieve a common } \\
\text { result }\end{array}$ & 51.5 & 38.1 & 8.2 & 2.2 \\
\hline Professionalism of other employees & 45.5 & 36.9 & 15.3 & 2.2 \\
\hline Positive thinking of other employees & 36.2 & 37.7 & 20.9 & 5.2 \\
\hline $\begin{array}{l}\text { Flexible and variable distribution of functions } \\
\text { between employees }\end{array}$ & 29.5 & 44.8 & 20.9 & 4.9 \\
\hline
\end{tabular}

The results confirm the need for mutual cooperation in the performance of daily duties for more than half of the employees of manufacturing enterprises. Noting in which of the stages of operation in the enterprise the mutual cooperation of employees is most needed, the respondents indicate: production planning and management (68.8\%), quality control, monitoring (52.6\%) and production technological process $(51.9 \%)$. In terms of cooperation, respondents consider less relevant such areas as: accounting and financial management, IT services, marketing and market research - the need for cooperation is indicated in $16.5 \%$ and $18.4 \%$ in each of the areas, respectively. (Table 3)

Table 3

The Most Relevant Operational Stage of the Manufacturing Enterprise for the Employees' Mutual Cooperation, Number, $(n=268) *$ Multiple Response

In which of the operational stages in the enterprise is the greatest need for the employees' mutual cooperation?

Count Response, \% (Base: Count)

\begin{tabular}{lll}
\hline Manufacturing planning and management & 183 & 68.8 \\
\hline Quality control, monitoring & 140 & 52.6 \\
\hline Technological process of manufacturing & 138 & 51.9 \\
\hline Installation, provision of operation, technical support, equipment maintenance & 123 & 46.2 \\
\hline Logistics (storage, warehouses, transport) & 119 & 44.7 \\
\hline Procurement of resources & 117 & 44.0 \\
\hline Designing, product development, design & 113 & 42.5 \\
\hline Sales, order processing, distribution organization, customer service & 101 & 38.0 \\
\hline Management, administration, strategic planning & 92 & 34.6 \\
\hline Personnel management & 59 & 22.2 \\
\hline Marketing and market research & 49 & 18.4 \\
\hline IT service & 49 & 18.4 \\
\hline Accounting and financial management & 44 & 16.5
\end{tabular}


Diāna LİDUMA, Inese LŪSĒNA-EZERA. Involvement of employees in operational planning of manufacturing enterprises: Latvia experience

PROBLEMS

OF MANAGEMENT

IN THE $21^{\text {st }}$ CENTURY

Vol. 16, No. 2, 2021

Studying the tendency of forming work groups in manufacturing enterprises, it has been concluded that the employees' work groups independent of the manager are formed in the company for team building (50.7\%) and mutual experience exchange (41.8\%) (Table 4).

\section{Table 4}

Formation of Employees' Work Groups Independent of the Manager in Manufacturing Enterprises, \% $(n=268)$

\begin{tabular}{lcc}
\hline Are employees' work groups independent of the manager formed in your company: & Yes & No \\
\hline To unite the team and strengthen traditions & 50.7 & 49.3 \\
\hline For the exchange of mutual experience & 41.8 & 58.2 \\
\hline To fulfil a customer's order on a daily basis & 40.7 & 59.3 \\
\hline To solve complex work assignments & 40.3 & 59.7 \\
\hline To deal with crisis situations & 30.6 & 69.4 \\
\hline To implement changes & 36.9 & 63.1 \\
\hline For project development & 35.4 & 64.6 \\
\hline For implementation of innovations & 29.9 & 70.1 \\
\hline For financing acquisition & 15.7 & 84.3 \\
\hline
\end{tabular}

The issues such as acquisition of financing (no - 84.5\%) and introduction of innovations (no $-70.1 \%$ ) are the least addressed in work groups in manufacturing enterprises (Table 4). $70.7 \%$ of respondents mention that during the last year they have been involved in the quality problem-solving issues, but another $61.9 \%$ in efficiency issues discussion and $56.3 \%$ in their own unit/ department's action plan development. (Table 5) Only $29.3 \%$, i.e., $\sim 1 / 3$ of employees are involved in the decisions about the change implementation in the company. Employees' involvement in a complex issue/problem solving relevant to the enterprise's operations (36.3\%) and product development (32.1\%) is also low. Only $16.3 \%$ of employees have been involved in defining the enterprise's goals in the last year (Table 5).

\section{Table 5}

Involvement of Employees in Problem-Solving Issues Relevant to the Company during the Last Year, Number, $(n=268)$ *Multiple Response

\begin{tabular}{lll}
\hline You have been involved during the last year in: & Count & Response, \% (Base: Count) \\
\hline Finding solutions to quality issues & 152 & 70.7 \\
\hline Discussion of efficiency issues & 133 & 61.9 \\
\hline Development of own unit/department's action plans & 121 & 56.3 \\
\hline Assessment of performance outcomes in the enterprise/department & 92 & 42.8 \\
\hline A topical, complex issue / problem-solving for the enterprise's operation & 78 & 36.3 \\
\hline Product development & 69 & 32.1 \\
\hline Decisions on change implementation in the company & 63 & 29.3 \\
\hline Cooperation development with various stakeholders & 59 & 27.4 \\
\hline At the enterprise's reputation promotion event & 47 & 21.9 \\
\hline The company goal defining & 35 & 16.3 \\
\hline
\end{tabular}


Diāna LİDUMA, Inese LŪSĒNA-EZERA. Involvement of employees in operational planning of manufacturing enterprises: Latvia experience

OF MANAGEMI

IN THE $21^{\text {st }}$ CENTURY Vol. 16, No. 2, 2021

The fact that only the enterprise's leading employees and specialists are involved in the development of the enterprise's development goals and plans has been indicated by $43.3 \%$ of the enterprise's employees. Also, in 34\% of cases, the enterprise's employees have mentioned the opinion that setting the enterprise's goals and planning development is only a task for the management. (Table 6)

Table 6

Involvement of Employees in the Development of the Enterprise's Development Goals and Plans, \% $(n=268)$

Are the enterprise's employees involved in the development of the enterprise's development goals and plans?

Column Valid $N$

Only the enterprise's leading employees and specialists are involved 43.3

Setting the enterprise's goals and development planning is only a task for the management

Finding out how inherent certain statements about decision-making in manufacturing enterprises are, it clearly appears that only the enterprise's management participates in the manufacturing enterprise's day-to-day decision-making (Mean rating $3.6(S D=1.078)$ ) and it is not at all typical that all employees are involved in decision-making (Mean rating 1.93 $(S D=1.010))$ (Table 7).

Table 7

Involvement of Employees Decision Making, Average Rating $(n=268)$

\begin{tabular}{lllll}
\hline $\begin{array}{l}\text { How inherent are the following statements in your enterprise } \\
\text { in daily life? }\end{array}$ & Min & Max & M & SD \\
\hline Only the enterprise's management participates in decision-making & 1 & 5 & 3.60 & 1.078 \\
\hline The head of the enterprise makes unilateral decisions & 1 & 5 & 3.33 & 1.163 \\
\hline Employees accept and support the decisions made in the enterprise & 1 & 5 & 3.09 & 1.126 \\
\hline Your line manager makes unilateral decisions & 1 & 5 & 3.08 & 1.154 \\
\hline $\begin{array}{l}\text { Decisions are made between employees within each unit / depart- } \\
\text { ment /among function performers }\end{array}$ & 1 & 5 & 3.07 & 1.104 \\
\hline $\begin{array}{l}\text { Employees of different functions and levels are involved in decision- } \\
\text { making }\end{array}$ & 1 & 5 & 3.05 & 1.048 \\
\hline Special work groups are formed to make difficult decisions & 1 & 5 & 2.87 & 1.326 \\
\hline All employees of the company are involved in decision-making & 1 & 5 & 1.93 & 1.010 \\
\hline
\end{tabular}

$53.3 \%$ of respondents have mentioned that only the enterprise's management participates in decision-making. The results also indicate that companies are inherent in unilateral decisionmaking by the manager $-45.5 \%$ of the respondents indicate that the enterprise's manager makes unilateral decisions, but $35.0 \%$ mention that unilateral decisions are also made by the line manager.

Regarding the need for employees' participation and involvement in various issues related to the management of manufacturing enterprises, $82.1 \%$ of respondents mention the need to involve employees in the division of tasks and responsibilities, but $71.3 \%$ - in 
Diāna LİDUMA, Inese LŪSĒNA-EZERA. Involvement of employees in operational planning of manufacturing enterprises: Latvia experience

setting work standards. $68.7 \%$ indicate that the involvement of employees in the development of the enterprise's strategic plans is not necessary and another $60.8 \%$ deny the need for the involvement of employees in the overall decision-making of the entire enterprise. $78.4 \%$ support the involvement of employees in the development of the goals and operational plans of their department (Figure 1).

\section{Figure 1}

The Need for Employees' Participation in the Management Issues of the Manufacturing Enterprise, \% $(n=268)$

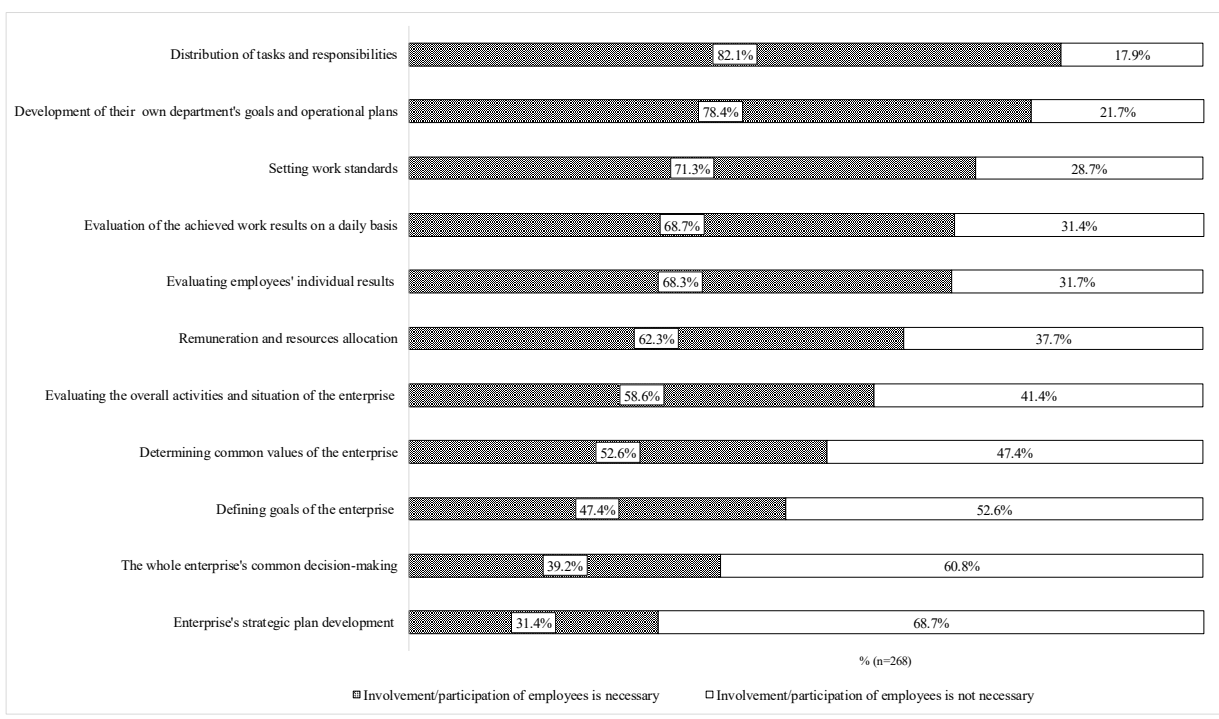

In terms of co-operation, the interaction among employees within one department has received a higher evaluation in the studied manufacturing enterprises. When giving evaluations of cooperation in their enterprise on a scale from 1 (very poor) to 5 (very good), the employees have evaluated as the best both the employees' interaction within one department (Mean rating $4.07(S D=0.747))$ and employees and management's cooperation within one department (Mean rating $3.74(S D=0.904)$ ) (Table 8$)$.

\section{Table 8}

\section{Evaluation of Cooperation in Manufacturing Enterprises, Average Rating $(n=268)$}

\begin{tabular}{|c|c|c|c|c|c|}
\hline & $N$ & Min & Max & $M$ & $S D$ \\
\hline Employees' interaction within one department & 268 & 2 & 5 & 4.07 & 0.747 \\
\hline $\begin{array}{l}\text { Employees and management's interaction within one } \\
\text { department }\end{array}$ & 268 & 1 & 5 & 3.74 & 0.904 \\
\hline Managers' interaction in the enterprise & 268 & 1 & 5 & 3.66 & 0.903 \\
\hline Employees' skills and willingness to collaborate & 268 & 1 & 5 & 3.59 & 0.767 \\
\hline $\begin{array}{l}\text { Employees' ability to act in a united and coordinated man- } \\
\text { ner }\end{array}$ & 268 & 1 & 5 & 3.51 & 0.897 \\
\hline $\begin{array}{l}\text { Employees and management's interaction in the enterprise } \\
\text { in general }\end{array}$ & 268 & 1 & 5 & 3.38 & 0.939 \\
\hline Employees' interaction between different departments & 268 & 1 & 5 & 3.37 & 0.912 \\
\hline Employees' ability to resolve conflicts & 268 & 1 & 5 & 3.35 & 0.930 \\
\hline
\end{tabular}

\begin{tabular}{l} 
OF MANAGEMENT \\
IN THE 21 $1^{\text {st }}$ CENTURY \\
Vol. 16, No. 2, 2021 \\
\hline 97
\end{tabular} 
Diāna LĪDUMA, Inese LŪSĒNA-EZERA. Involvement of employees in operational planning of manufacturing enterprises: Latvia experience

PROBLEMS

OF MANAGEMENT IN THE $21^{\text {st }}$ CENTURY Vol. 16, No. 2, 2021

Employees' interaction between different departments (Mean rating $3.37(S D=0.912)$ ) and employees and management's interaction in the company in general (Mean rating 3.38 $(S D=0.939))$ have received a low average rating. Managers' interaction in the enterprise has been rated higher: mean rating $3.66(S D=0.903)$ (Table 8$)$.

Taking into account the low evaluation given by the employees to the mutual cooperation between different departments ( $15.3 \%$ of the respondents mention it as bad; mean rating is 3.37 $(S D=0.912))$, it can be concluded that the work environment within one department is more positive for teamwork.

\section{Discussion}

The studied manufacturing enterprises only partially correspond to the features of an efficient organization (Zinkevich-Evstigneeva, 2004). The employees of the enterprise mention the company's interest in finding out and satisfying the needs of customers efficiently as the most characteristic. This is justified in market conditions. But the features of an efficient organization, which are associated with teamwork - employees' involvement in common problem-solving, application of employees' initiative and the enterprise's ability to operate as a whole, are less characteristic. Even though more than $70 \%$ of the employees' day-to-day responsibilities in manufacturing enterprises are related to cooperation and 51.5\% are "largely" related to the ability to work together in order to achieve a common result, the issues related to joint business planning and acquisition of a unified view in manufacturing enterprises have been neglected, preventing from the opportunity to make a full use of the previously theoretically substantiated advantages of the enterprise from the employees' involvement in these issues. In the frame of High-Performance Industrial Manufacturing, through the Industry standard 4.0. an importance of employee cooperation in manufacturing enterprises was highlighted also by Sandengen et.al. (2016), because in order to succeed with a complex technological integration, i.e., advanced Automation and Robotics, sensor-based computer technology, interconnected by wireless communication, and supported by BIG Data solutions, manufacturing enterprises need effective management and excellent Human/ Human cooperation, and thus, according to Sandengen et al (2016), effective management and human cooperation will be increasingly important in the future (Sandengen, et al., 2016).

Answering the research question and revealing the areas of the enterprise's activities in which employees have been involved, it has been concluded that in the last year most of the employees $(70.7 \%)$ have been involved in addressing quality issues and discussion of efficiency issues (61.9\%). Employees' work groups independent of the manager in manufacturing enterprises are mainly formed for teambuilding $(50.7 \%)$ and mutual experience exchange (41.8\%). A partially positive result is the involvement of $56.3 \%$ of employees in the development of business plans of their unit/ department, but only $16.3 \%$ of employees have been involved in defining the enterprise's overall goals over the past year. $43.3 \%$ of the respondents indicate that only the company's leading employees and specialists are involved in the development of the enterprise's development goals and plans, where most of the employees believe that this is also an area applicable only to managers. Employees' involvement in solving a complex issue / problem relevant to the enterprise's operations (36.3\%) and product development (32.1\%) during the last year has also been low. About $1 / 3$ of employees have been involved in decisions about the implementation of changes in the company, which does not convince of a supportive work environment in order to create a common understanding of values in the enterprise. The results reveal that only the management of the company participate in the daily decision-making of the manufacturing enterprise, and it is not at all typical that all employees of the company are involved in decision-making. Unilateral decision-making by the manager is typical at the level of both the enterprise's management and department managers. The boundaries of mutual 
cooperation within only one department are supplemented by the evaluation of cooperation Vol. 16, No. 2, 2021 provided by employees in enterprises. In terms of co-operation, in manufacturing enterprises, employees' interaction within the same department, both between employees and between employees and management, has been rated higher. The employees' interaction between different departments and employees and management's interaction in the enterprise in general has obtained the lowest average rating. Taking into account the low evaluation given by the employees to the mutual cooperation between different departments $(15.3 \%$ of the respondents mention it as bad; mean rating is $3.37(S D=0.912)$, it can be concluded that the work environment within one department is more positive for teamwork. By covering the enterprise's processes at multiple levels and operating in parallel and independent directions, not only the top-level corporate executives but also the middle and operations managers and their teams who manage the fundamental processes by getting engaged in strategic decisions, can provide the corporate management with a holistic view of what specific companies can do today and what could be achieved in the future by identifying a set of plans, programmes and actions that should direct the enterprise's strategy (Bower \& Gilbert, 2009).

The results show that the employees' participation in the operation of manufacturing enterprises, from the employees' point of view, is most necessary in the division of tasks and responsibilities, development of goals and operational plans of their department, as well as in determination of work standards, but the least interest is in the involvement in the development of the enterprise's strategic plans and the whole enterprise's common decisionmaking. Looking at the need for the employees' participation in solving specific functions, it is the most relevant, form the employees' point of view, in business flows that add the value (according to Svikis, 2018) - in production planning, management, technological processes and quality determination, but less relevant - in supporting action flows that do not add the value (accounting, IT, marketing, personnel management). The results show that employees appreciate the need for cooperation in those areas in which they have been involved so far. The employee, who has been involved in the team so far to solve a certain issue, has also assessed the importance of mutual cooperation in the respective field. Importance of team in the manufacturing enterprises was concluded also by Davila et al. (2016) which find out that by focusing on performance and team development, manufacturing enterprises ' performance was significantly improved by enhancing manufacture planning and control capabilities, product development capabilities and by structuring commercial functions (Davila et al., 2016).

It can be assumed that the involvement of employees and promotion of cooperation in other areas relevant to the enterprise's operations would allow to appreciate the advantages provided by the teamwork in the progress of issues in these areas in the manufacturing enterprises as well.

\section{Conclusions}

Such teamwork features in the enterprise as the understanding of a common goal and development of mutual cooperation, also mean the employees' involvement in decision-making, business planning and strategic issues, which results in a common understanding of values within the enterprise and provides support in the performance of duties among performers of different levels and functions. Equally, such involvement of employees and teamwork are also a sign of a strong corporate culture that contributes to the enterprise's sustainability. However, the results of the study enable us to conclude that the involvement of employees in decision-making and goal setting has been observed only within their own department. Quality and efficiency issues are addressed through the involvement of employees. The results show insufficient involvement of employees in the manufacturing enterprises' planning - in strategic issues. Therefore, a common concept of what a particular enterprise can do today and what it could achieve in the 
Diāna LĪDUMA, Inese LŪSĒNA-EZERA. Involvement of employees in operational planning of manufacturing enterprises: Latvia experience

OF MAN

NAGEMENT

IN THE $21^{\text {st }}$ CENTURY Vol. 16, No. 2, 2021

100

future is underestimated. The involvement of employees provides an opportunity to receive more information, knowledge and experience for diverse solutions. This shortcoming may be felt by manufacturing enterprises that have not appreciated the involvement of employees in business planning.

To a certain extent, the results indicate the need to develop the skills of manufacturing enterprises' managers to delegate and acquire knowledge in teambuilding, as there is a tendency for managers to make unilateral decisions. Work groups are formed to unite the team, strengthen traditions, and exchange mutual experience. At the same time, from the employees' point of view, cooperation is the most relevant in production planning and management, quality control, as well as in the manufacturing technological process. Employees want to be involved in such issues as: "distribution of tasks and responsibilities", "determination of work standards", "development of goals and operational plans for their department".

\section{Declaration of Interest}

Authors declare no competing interest.

\section{References}

Adizes, K.I. (2018). Prasmīga pārmainu vadība: ievads organizāciju terapijā [Mastering change: Introduction to organizational therapy] Publishing House Zvaigzne ABC.

Barets, R. (2008). Vērtīborientētas organizācijas izveide: visas sistēmas kultūras transformācijas koncepcija. [Formation of a value-orientated organization] Society "Domas spēks".

Bikfalvi, A. (2011). Teamwork in production: Implementation, its determinants, and estimates for German manufacturing. Human Factors and Ergonomics in Manufacturing \& Service Industries. 21(3), 244-259. https://doi.org/10.1002/hfm.20230

Blančards, K., \& Džonsons, S. (2008). Efektīvas vadības noslēpumi. [The one minute manager] Publishing House Zvaigzne ABC.

Bote, T. (2017). Kā atšksirt komandu no kolektīva. [How to distinguish the team from the collective]. Mondey, 14/02/2017.https://www.monday.lv/ka-atskirt-komandu-no-kolektiva/

Bouvers, Dž., \& Gilberts, K. (2009). Kā vadītāju ikdienas lēmumi veido vai izjauc jūsu uznēmuma stratēgiju. [As managers, everyday decisions shape or disrupt your business strategy]. In Stjuarts. T. (Eds.), Stratēgijas atjaunošana [Harvard Business Review on Strategic Renewal] (pp.125139). Business Information Service.

Caune, J., \& Dzedons, A. (2009). Stratēgiskā vadī̌̌ana. [Strategic management]. Publishing House "Lidojošā zivs".

Dávila, G. A. et al. (2016). Learning to grow: How micro and small enterprises from Santa Catarina Face growth challenges. Navus - Revista de Gestão e Tecnologia, 6(3), 6-23. https://doi.org/10.22279/navus.2016.v6n3.p6-23.391

Flores-Fillol, R., Iranzo, S., \& Mane, F. (2017). Teamwork and delegation of decisions within the firm. International Journal of Industrial Organization. 52, 1-29. https://doi.org/10.1016/j.ijindorg.2017.01.008

Forands, I. (2003). Personāla vadība. [Personnel management]. Latvia Education Fund.

Frīmentls, D. (2006). Komandas motivācija un vadība. 50 praktiski padomi [Little things that make big difference to team motivation and leadership]. Publishing House Zvaigzne ABC.

Grant, K. P., \& Hallam, C. R. A. (2016). Team performance in a lean manufacturing operation: It takes the will and a way to succeed. International Journal of Technology Management, 70(2), 177-192. https://dx.doi.org/10.1504/IJTM.2016.075161

Gratone, L. (2004). Cilvēkresursu stratēgija [Human resources strategy]. Jumava.

Hill, A. L., Brando, G., Trūlava, E., \& Lainbeks, K. (2014). Kolektīvais gēenijs. Inovāciju vadības māksla un prakse [Collective genius, the art and practice of innovation management]. Publishing House "Lauku avīze".

Hofs, K. G., \& Alsiṇa, R. (2019). Biznesa ekonomika [Business Economics]. DCS. 
Diāna LİDUMA, Inese LŪSĒNA-EZERA. Involvement of employees in operational planning of manufacturing enterprises: Latvia experience

PROBLEMS

OF MANAGEMENT

IN THE $21^{\text {st }}$ CENTURY

Vol. 16, No. 2, 2021

Kristensens, K., Markss, M., \& Stīvensons, H. (2009). Sadarbības un pārmainu instrumenti [Cooperation and change tools]. In Stjuarts T. (Eds.), Stratēgijas atjaunošana [Harvard Business Review on Strategic Renewal] (pp.163-180). Business Information Service.

Maginn, D. M. (1994). Effective Teamwork. McGrow-Hill

Menkinss, M., \& Stīls, R. (2009). Pārstājiet veidot plānus, sāciet pieṇemt lēmumus. [Stop making plans, start making decisions]. In Stjuarts T. (Eds.), Stratēgijas atjaunošana. [Harvard Business Review on Strategic Renewal] (pp.141-161). Business Information Service.

Ozolinga-Ozola, I. (2009). Efektivitāte un produktivitāte [Efficiency and productivity]. Biznesa Psihologiija, $19,44-48$.

Owen, J. (2017). The leadership skills handbook. Kogan Page.

Praude, V. (2012). Menedžments. 1. Grāmata. [Management. Book 1]. Publishing House "Burtene".

Ruperte, I. (2010). Uzñēmuma vadīšana. İsi par galveno teorijā un praksēe. [Business management. briefly on the main theory and practice]. Publishing House "Jumava".

Sandengen, O. C., Estensen L. A., Rødseth, H., Schjølberg, P. (2016). High performance manufacturing an innovative contribution towards industry 4.0. In: Appolloni, A., Caracciolo, F., Ding, Z., Gogas, P., Huang, G., Nartea, G., Ngo, T., \& Striełkowski, W. (Eds.). Advances in Economics, Business and Management Research (Vol.24, pp. 14-20). https://doi.org/10.2991/iwama-16.2016.3

Sinicins, M. (2009). Ekonomika. [Economics]. Publishing House RaKa.

Svikisis, A. (2018). Matric tīklojums. Oriğināls biznesa pārvaldības modelis [Matric networking. Original business management model]. Publishing House Zvaigzne ABC.

Vīksna, A. (2009). Savs bizness. [Own business]. Business Information Service.

Wellington, P. (2017). Effective people management. Kogan Page.

West, M. (2004). Motivate teams, maximize success. Chronicle Books LLC.

Sartan, G. (2005). Trening komandoobrazovaniya. [Training of Team Building]. Publishing House Rech

Zinkevich-Evstigneeva, T. D. (2004). Teoriya i praktika komandoobrazovaniya: Sovremennaya tehnologiya sozdaniya komand. [Theory and practice of team building: Modern technology for creating teams]. Publishing House Rech.

Received: November 16, 2021

Accepted: December 08, 2021

Cite as: Līduma, D., \& Lūsēna-Ezera, I. (2021). Involvement of employees in operational planning of manufacturing enterprises: Latvia experience. Problems of Management in the $21^{\text {st }}$ Century, 16(2), 87-101. https://doi.org/10.33225/pmc/21.16.87

\begin{tabular}{|c|c|}
\hline $\begin{array}{l}\text { Diāna Līduma } \\
\text { (Corresponding author) }\end{array}$ & $\begin{array}{l}\text { Mg.oec., Lecturer, Liepaja University, } 14 \text { Liela Str., Liepaja, LV-3401 Latvia. } \\
\text { E-mail: diana_liduma@inbox.Iv } \\
\text { Website: https://www.liepu.Iv/en/researchers/69/diana-liduma }\end{array}$ \\
\hline Inese Lūsēna-Ezera & $\begin{array}{l}\text { Dr.sc. admin., Professor, Liepaja University, } 14 \text { Liela Str., Liepaja, LV-3401 } \\
\text { Latvia. } \\
\text { E-mail: inese.lusena-ezera@liepu.Iv } \\
\text { ORCID: https://orcid.org/0000-0002-0943-7431 }\end{array}$ \\
\hline
\end{tabular}

